\title{
Sicilian Language
}

National Cancer Institute

\section{Source}

National Cancer Institute. Sicilian Language. NCI Thesaurus. Code C154109.

A Romance language spoken on the island of Sicily and its satellite islands. 